\title{
Spatial Configuration of Fishing Village in Bagan Deli Belawan Medan Indonesia
}

\author{
B O Y Marpaung ${ }^{1}$, Dwira Nirfalini Aulia ${ }^{1}$, M Nawawiy Loebis $^{1} \&$ M D Cahya ${ }^{1}$ \\ ${ }^{1}$ Departement of Architecture, Faculty of Engineering, Universitas Sumatera Utara, Indonesia \\ Correspondence: B O Y Marpaung, Architecture Department, Faculty of Engineering, Universitas Sumatera \\ Utara. Jl. Perpustakaan, Kampus USU Gedung D, Padang Bulan, Medan Baru, Kota Medan, Sumatera Utara, \\ Indonesia. Tel: 62-81-161-7121. E-mail: beny.marpaung@usu.ac.id
}

\author{
Received: May 20, 2019 Accepted: June 18, $2019 \quad$ Online Published: June 30, 2019 \\ doi:10.5539/ass.v15n7p103 URL: https://doi.org/10.5539/ass.v15n7p103
}

\begin{abstract}
Spatial planning in the context of configuration will form a balance of spatial patterns and structures. Spatial patterns related to factors that influence such as spatial patterns formed by economic, social, religious, political, government regulations and natural factors. Based on the above factors, this research has several problems, namely the influence of activity in forming the relationship between spaces, then how the relationship pattern of space is formed, and how it is configured in the settlements of the fishing village of Bagan Deli in Belawan Medan. To assist in the process of this research, several methods were chosen. The method used is the method of determining the location by considering which location is good to be researched and determined intentionally (purposive method), then the method of determining variables by first identifying interpretations of theoretical foundations, and methods of data analysis that produce activity discoveries that influence the formation of the relationship between space, then the relationship between the space formed in the settlements of the fishing village, and the spatial configuration in the fishing village of Bagan Deli in Belawan Medan.
\end{abstract}

Keywords: configuration, fishing village, settlement, spatial planning

\section{Introduction}

The shape of space affects how space is used and the patterns of activity that occur in space. About activity patterns, the square shape of space causes activities that tend to occur centrally or focus on space. Then, the form of linear space will affect the pattern of activity that tends to be dispersed. Activities and space have a close relationship because space has no meaning if there is no activity in it. When activity occupies space, there will be a tendency where activity occurs in space. In completion, the activity of occupying space can occur centrally, for example, in an open space in the form of a square with an irregular square shape. Also, the activity can also occur in the spatial space with linear patterns and roads in settlements (Figure 1).
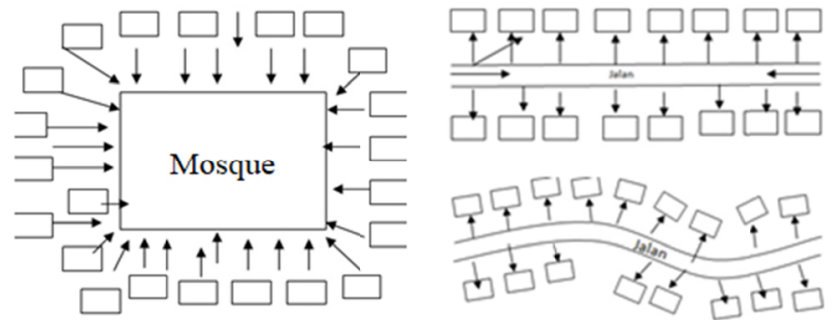

Figure 1. The centralized activity takes place at the mosque and activity in the linear space occurs on the street

Activities that occur on the road will certainly be related to the road patterns that are formed so that their existence can be spread according to the reality of the formed patterns. Social life can occur in public open spaces that were originally designed and planned for various functions. The social life in the settlement does not escape the life events in it. Life in outer space in settlements can occur in a planned way. However, it does not rule out the possibility that the outer space that is formed naturally or unplanned can become a place for the process of social life of its inhabitants. Also, space in the planned settlement is not a public open space; it can also be a place for residents to live. The formation of a settlement environment is reflected in the relationship between individuals, families, and society. How each relates to the family and the surrounding environment and 
of course differs from one culture to another, this leads to the spatial organization and layout of the residential area, depending on the views of each life (Dansby, 1993, p. 137). Culture varies from place to place, between one tribe and another, between one religion and another. Culture has the characteristics of each differentiation between one another.

In each settlement, the majority of people with cultural similarities will have greater decisions or agreements, and the formation of such settlements is always determined by the culture of the majority of the local population. This leads to the formation of a residential environment based on the majority of the population. Every culture always upholds the values and norms of decency that are interconnected and interact with the family and the surrounding environment. The arrangement and design of space depend very much on the individual's view of life. It is not impossible for cross-cultural events that can unite the minds of one individual with another to create new views that determine and influence the formation of a settlement environment. When cultural or cross-cultural exchanges lead to cooperation in the formation and construction of settlements. Uniting opinion mind is very important because the cultural exchange is very beneficial for every human being because humans are social beings who need each other and work together (Figure 2). To explain the meaning of organizational space in the context of place and space must be related to culture (Tuan, 1977).

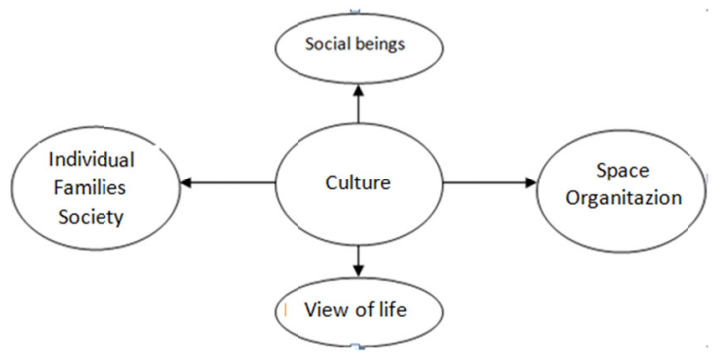

Figure 2. Cultural linkage with other factors

In figure 2 culture has an important role in meaning and forms a space organization. Every individual interacts with other individuals. How space is related to culture depends on the view of each life and each culture has its view. Values about habits and culture are always associated with values of faith or religion that determine the organization of space. It's like following a religion that always sorts and arrange space according to functions and benefits in a particular religion or culture. This is made because of the prohibition or taboo of certain cultures or religions that are believed and regulates the organizational space. The need or function of each culture or religion determines what activities will be carried out in that space later. In culture, there are certain laws or taboos in determining the formation of space based on their respective functions. It depends on every society who believes in their respective cultures.

Spatial configuration is interpreted as a spatial relationship pattern that forms an arrangement so that it has meaning that can be read and understood by everyone. Configuration as a concept that refers to all things that are more complicated than parts (Hillier, 2007). Formation of the spatial composition begins with ideas or designs made from thoughts, ideas, and reasons. Is it an individual's idea or group idea about space formation. This space arrangement is ultimately designed according to the experience of past learning processes to shape, create and design space settings (Figure 3).

\begin{tabular}{|c|c|c|}
\hline Ideas, minds & Learn from & Forming the composition \\
\hline and reasons & the past (experience) & of space \\
\hline
\end{tabular}

Figure 3. The process of forming a spatial arrangement

The composition of the space formed has its style that will form space and be understood by everyone who inhabits a room or visits space because of the impression of space experience. The experience of space by one individual with others is very different. It all depends on the interpretation or how someone assesses and feels their experience. From this interpretation will make many changes in space over time based on experience. The effect of spatial configuration is not so much felt by individuals but in the lives of groups and how they relate through space. The pattern of space in settlements can influence the pattern of joint attendance and mutual awareness of the gathering of people who inhabit and visit settlements (Hillier, 2007, p. 293). The influence of the shape of the space will not be felt and cannot be used only by one person or one individual, but the effect will be seen and felt in a group of individuals who inhabit space. Every individual or everyone is connected through space. 
Andi U. Fery (2017) revealed that the configuration of buildings that are arranged linearly along the path and boundary of the river could be said to be the spatial configuration of the Linear pattern. This spatial configuration as a space that follows an outline or a straight line and the arrangement of buildings that are neatly arranged follows a straight line according to the banks of the river. Just like ancient traditional societies that rely on rivers as a source of life and the use of rivers as a means of transportation, spatial planning is formed which follows an outline or a straight line which is none other than the river line itself.

Andi U. Fery (2017) also revealed that spatial configurations that develop without patterns and irregularity, spontaneously and wildly follow the circulation path and layout of existing buildings are said to be sporadic spatial configurations. Spatial configuration (spatial form or shape) is formed and develops without skin, without planning and tends to be irregular, uncluttered, tangled and chaotic. The arrangement of spontaneous and unplanned places is formed by impulses, and there is no suggestion from anywhere, setting a wild and poorly maintained, unkempt place that follows a straight or longitudinal line from the circulation and layout of existing buildings from afar, made from the past and pre-existing building layout. Spatial configuration as a set of lines that represent the uninterrupted direction of movement and visibility and covers all areas of the plan and all ways of moving around one dimension (1-D) and two dimensions (2-D) located within it (Hillier \& Hanson, 1984, p. 99)

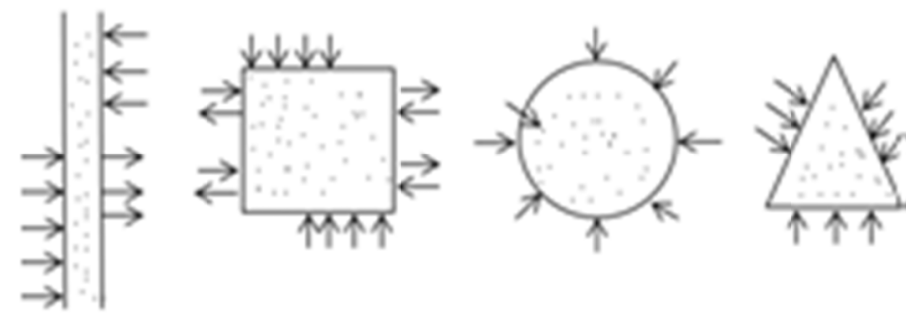

Figure 4. Activities that occur in two-dimensional areas

In Figure 4 we can also see that every spatial activity will not be disturbed provided all activities move in a one-dimensional field from the composition of space in only one path such as the road network in the composition of the settlement space and all activities in a two-dimensional area from the composition of space contained in the element long or wide, which can be arranged in a flat building such as triangles, squares, etc.

\section{Method}

This research is based on visual surveys, photographs, field records and observations of several existing environments. Hence the method of determining the location of the study was determined intentionally (purposive method) to be conducted in the Fishing Village in Bagan Deli Medan Belawan.

1) Method of determining the location

Research locations are settlements with unplanned space and living arrangements

The research location is the settlement of people who live in coastal areas and have a livelihood as fishermen.

2) Method of determining the variable.

In determining the research variables, researchers must first identify the interpretation of the theoretical foundation. The theory used is a theory that is closely related to the Spatial Configuration in Fishing Village Belawan Bagan Deli, Medan. In the recitation, researchers relate the theory to be studied with research problems.

3) Method of collecting data.

After determining the research variables, this will be very helpful in the process of obtaining the data needed in the data collection method. This method will be supported by surveys, interviews, literature, statistical data, and mapping.

4) Methods of analyzing data.

Linking problem formulation and theory supported by data that has been obtained.

\section{Results}

Use of space in the fishing village Bagan Deli fully utilizes the main road. Shopping activities occur on the main road as traditional markets and areas for children to play. 


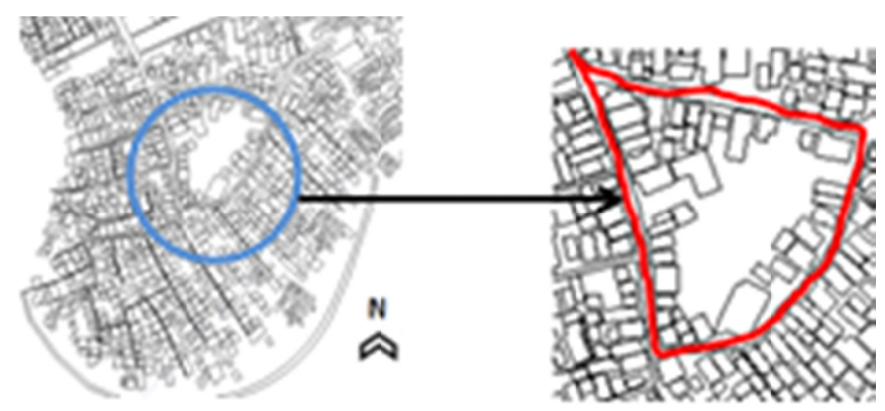

Description:

Main street in Fishing village Bagan Deli

Activities occur in a linear space, for example in a street that is converted into a traditional market. Utilization of the linear form of space in the fishing village of the main road Bagan Deli Belawan Medan affects the activity in it.

Activities that occupy space can occur centrally for example in an open space in a square. This happened at Nurul Hilal Mosque.

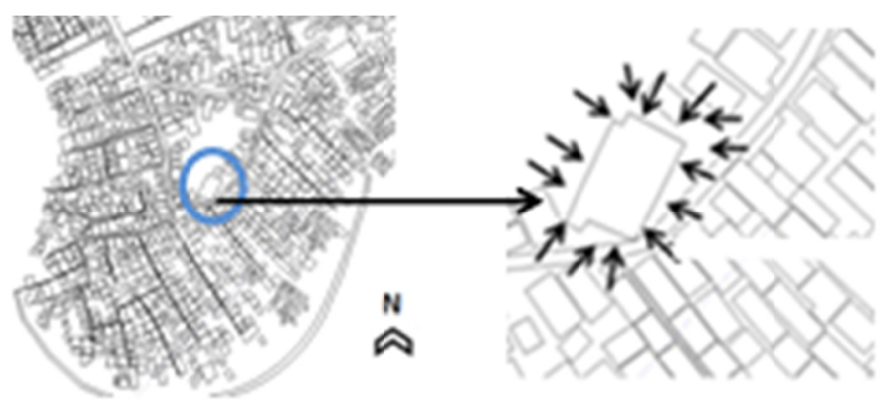

Working as fishermen and tribal-Malay, and Muslim communities, this similarity makes it easier for people to form spatial relations in their settlements, from the rules of their culture in determining space for other agreements.

The space pattern that forms the mass of mosque buildings makes the mosque's courtyard space can be used by the community, both adults and children, to sling interact or play. The pattern of space formed generally occurs on the main street and narrow alleys.

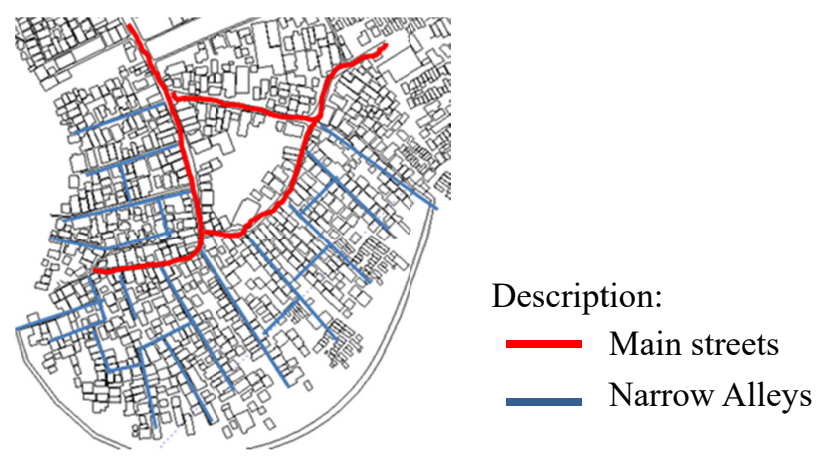

Regarding configuration. The building or house of a fisherman is built following the coastline based on the cognition or belief of a person or group which is a fishing profession from what is believed and obtained from the thinking process and considering matters relating to space. So that the formation of this fishing village is formed with the consideration of the sea as the main factor.

Construction of settlements or houses of the fishing village of Bagan Deli begins to follow the coastline (1). As long as there is still land that can be used as a place to live, then the construction of houses that will be occupied by fishermen in the fields of fishing fields (2) \& (3). 


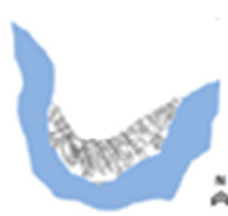

(1)

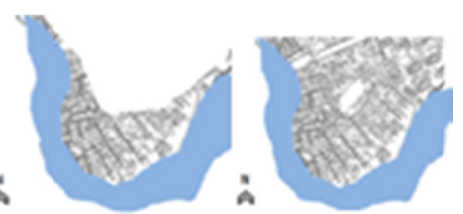

(2)

(3)

\section{Discussion}

\subsection{Fishing Village Belawan in Medan City}

The research is located in the coastal area of Medan City. The form of fishing village's settlement in Belawan Medan, especially in the village of Bagan Deli is very unplanned and disorganized (Figure 5). The houses of people standing on muddy land that caused seawater made them build on wood and concrete foundations as support for their homes. These houses are connected with self-made corridors without government intervention. This corridor has a width of $1.2 \mathrm{~m}-1.5 \mathrm{~m}$ with wood and small concrete then printed. Forms of settlements located in areas adjacent to the sea are formed unplanned and usually stand on illegal land. Meanwhile, for settlements located in areas adjacent to the main road are buildings that stand on their land.

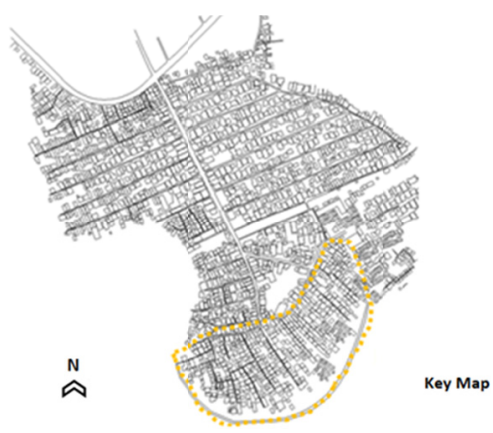

Figure 5. Research Location Map

From the pictures above (Figure 6), the road network and the accessibility of the residential area in the fishing village of Bagan Deli Belawan Medan. There are several roads that are quite wide that can be passed by four-wheeled vehicles and motorbikes. For people whose houses are directly adjacent to the waterfront, only small corridors can be used for daily access, the corridor is not more than 1.5 meters wide, so it can only be passed on foot. There is also a long bridge that connects citizens' access (Figure 7). This bridge has a width of 2.5 meters. This bridge is quite wide for motorbikes to pass through, but access to the bridge is very narrow so it can only be passed on foot. In this area are unplanned settlements from the fishing village of Belawan Medan Bagan Deli which stands not on their land. In this area are also often affected by flooding caused by sea waves with an altitude that sometimes reaches 1 meter. Even residential homes that live in this area will sink at certain times when sea water is tidal with a height of up to 1.5 meters.

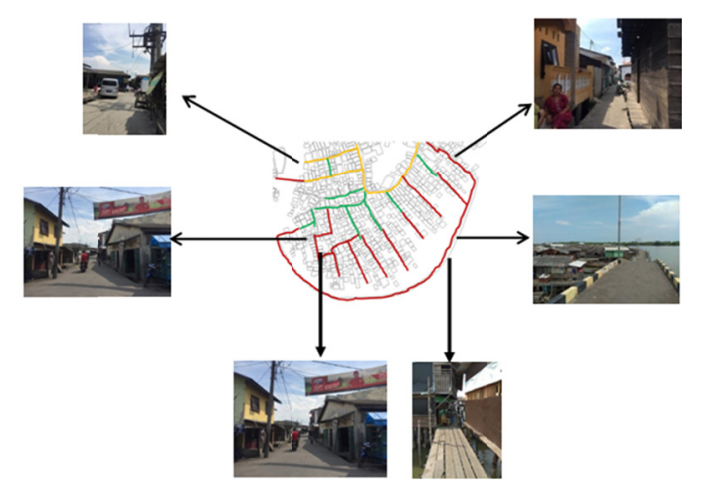

Description:

The streets that can be traveled by car and motorcycle

The streets that can only be passed by motorcycle, bicycle, and walk

The road is a small alley that can only be passed by foot

Figure 6. Existence of outer space on the street in Bagan Deli settlement 


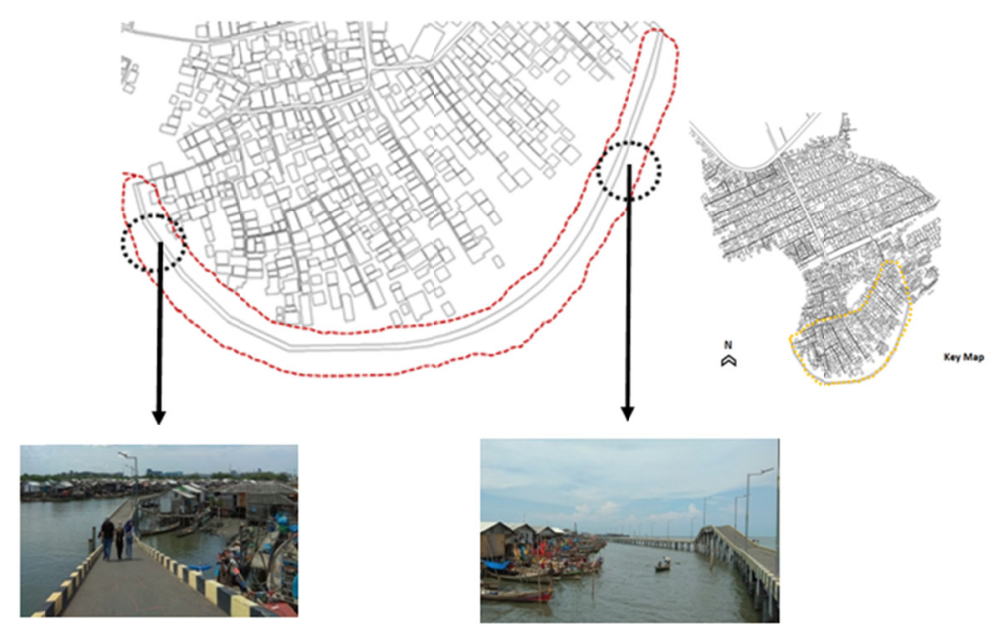

Figure 7. The shape of the bridge and its location

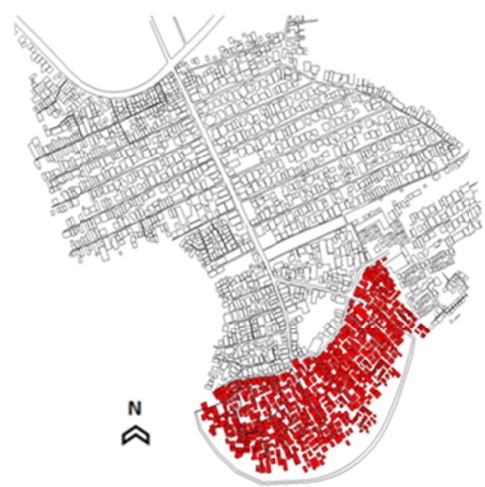

\author{
Description: \\ The settlements are standing on the sea and muddy ground \\ The settlements are standing on hard and solid soil
}

Figure 8 . The position of the unplanned building

From the picyure above (Figure 8), settlements that build in the sea or the muddy land are unplanned settlements that stand on land, not theirs. Whereas settlements that stand on hard and dense land are settlements that have ownership rights. Usually, buildings that stand on land that have property are located and face directly with the main road that can be passed by vehicles, both cars, and motorbikes. And buildings that stand in red areas are unplanned buildings and only have small corridors for accessibility.

\title{
4.2 Influence of Activities in Building Interspace Relations in Fishing Village Belawan
}

Fishing Village settlement in Bagan Deli Belawan is a settlement that was built unplanned by the community. The community works as fishermen and the majority of Malay ethnic groups. This settlement is located on the beach of Belawan Medan. This settlement was formed because of the need for people to survive. This fishing village community depends on the sea. Activities in this fishing village settlement are interesting because of the limited space to move.

Villages still have limited space such as main road corridors and narrow corridors to support daily activities and activities. Form of space affects how space is used and the pattern of activity that occurs in space. About activity patterns, the square shape of space causes activities that tend to occur centrally or focus on space. Then, the linear form of space will influence the pattern of activity that tends to spread. Activity and space have a close relationship because space has no meaning if there is no activity in it. When activity occupies space, there will be a tendency where activity occurs in space. In settlements, space exploration activities can occur from the center to the square in the open space even though the square is irregular. Also, the activity can also occur in spatial spaces with linear patterns such as roads in settlements. Activities that occur on the road will certainly be related to the road patterns that are formed so that their existence can be spread according to the reality of the road patterns that are formed. Activities such as shopping for vegetables cause the function of the road to turn into a vegetable market, and space on the street is also used for children's play areas.

The mosque on the site will be a magnetic orientation of the community's social activities. This area is also used as a play area for children (Figure 9). 


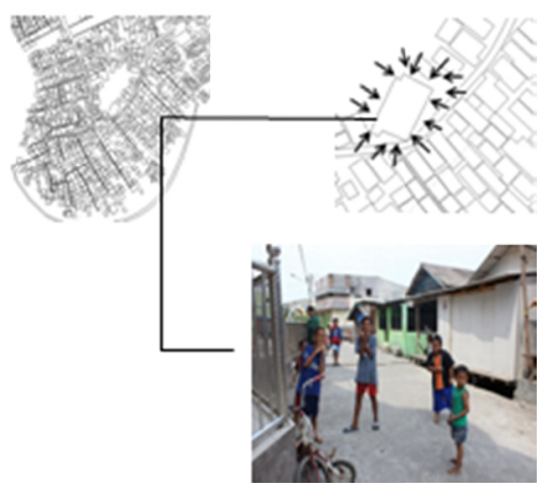

Figure 9. Social activity occupies a linear space centered in mosque

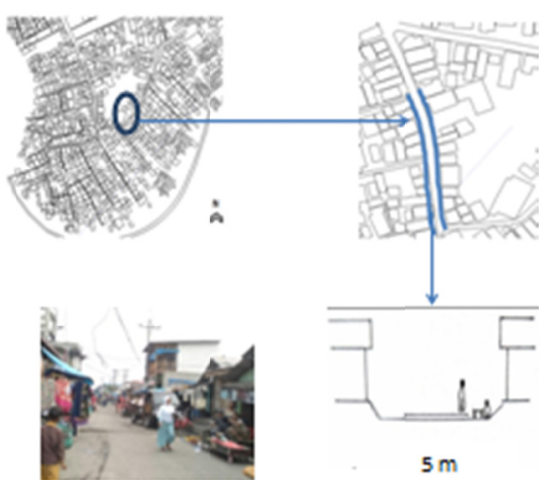

Figure 10. Activities Can Occur In A Linear Space

The road as a linear patterned space (Figure 10). Activity in linear space can occur on the road. These roads can be used as traditional markets by the community. In the fishing village settlement Bagan Deli Belawan Medan there is a place that serves as a space to accommodate daily activities.

Description:

House Standing on the sea

Nurul Hilal Mosque

House on Muddy Ground

Musholla

School

Commercial House

Funeral

Fish Shelter

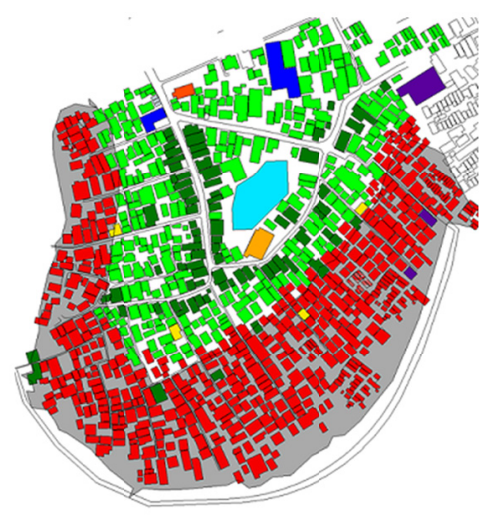

Figure 11. The settlement of the fishing village of Bagan Deli Medan

Description:
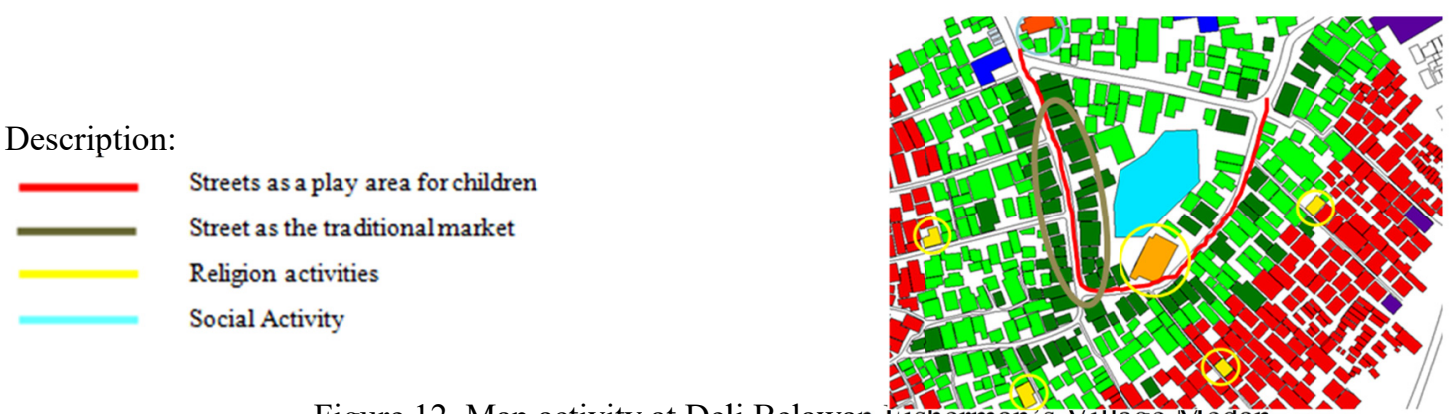

Figure 12. Map activity at Deli Belawan Fisherman s viliage Mleđan 
The picture illustrates all the places that support the occurrence of activities in the fishing village of Bagan Deli Belawan Medan (Figure $11 \& 12$ ). Starting from the daily activities of residents such as shopping activities, community interaction, religious activities, until children play activities.

Children will play on the main streets due to lack of adequate playgrounds. In addition to children's play activities, buying and selling activities among residents also occur in this fishing village such as shopping at the vegetable market that occurs on the main road. Usually, the activity in the vegetable market only occurs in the morning. Then the worship activities took place at the main mosque in this fishing village in Nurul Hilal Mosque and several prayers room. Social life can usually occur in public open spaces that were originally designed and planned for different functions. This social activity took place in the fishing village of Belawan Medan Bagan Deli. That is utilizing the main roads and changing functions that can be used as a place to hold weddings and cleaning activities by the community.

The main road in this fishing village can be transformed into a traditional market in the morning (Figure 13). This is where the villagers fulfill their food needs. Activities that take place at this traditional market begin at 6:00 a.m. - 11:00 p.m. There are several vegetable stalls, and there are even some traders who use space on the main road of this fishing village to sell vegetables.

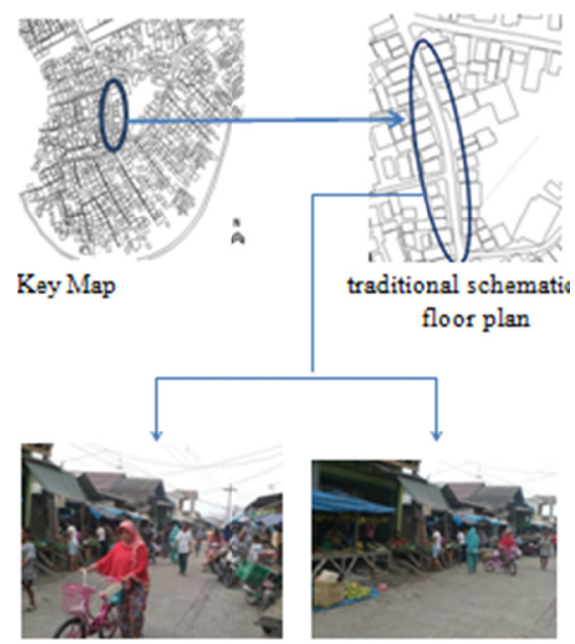

Figure 13. the Traditional market atmosphere in the Deli fisherman's village

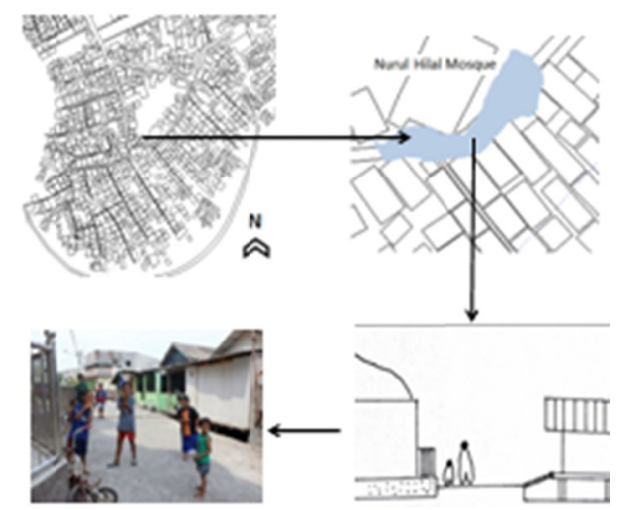

The atmosphere outside space on the Nurul Hilal Mosque

Figure 14. Space between Nurul Hilal Mosque and the row of residential buildings

Children's play activities take place in front of Nurul Hilal Mosque (Figure 14). The playroom is supported by the mosque building as a place of worship and the mass of buildings oriented towards the main road in this fishing village. The wide space in this position is formed very wide because of the position of the mosque which has a section of the building back as far as 5 meters.

The linear shape of space will influence the pattern of activity that tends to be dispersed. Not all activities take place in space. The social activities of children and residents only occur in certain places. This activity occurs because there is a burning function which is the mosque. The existence of the mosque triggers children's play 
activities and other activities such as residents meeting and chatting on the street right in front of the mosque. The mass rows of residential buildings in front and side of the mosque also support the socialization of residents in the fishing village of Bagan Deli Belawan Medan.
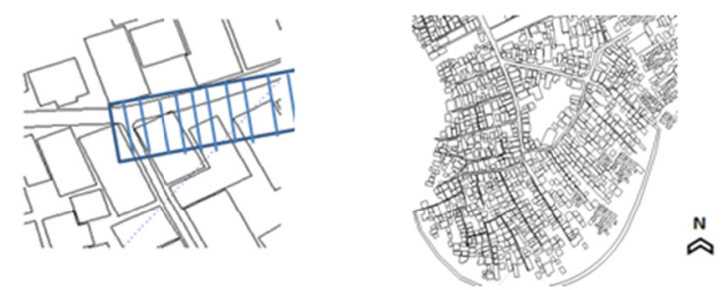

Space is formed by a row of buildings built by occupants who are oriented towards the street

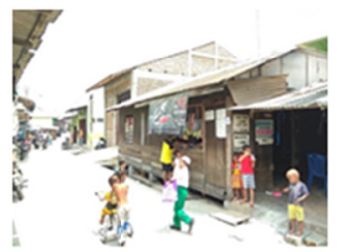

Figure 15. Elongated space formed by a row of street-oriented building masses

The space formed by the road-oriented mass sequence is always used for various activities (Figure 15). The most dominant activity in the space formed by the mass ranks was a meeting between residents considering that each building was oriented towards the road. The space formed is usually used by children to move and play. In general, almost all activities occur on the road given the limited land available. This fishing village is a village that stands on the shoreline; flooding often occurs when the tide is high. This is what hinders the occupants of the activity because the roads are submerged in tidal water.

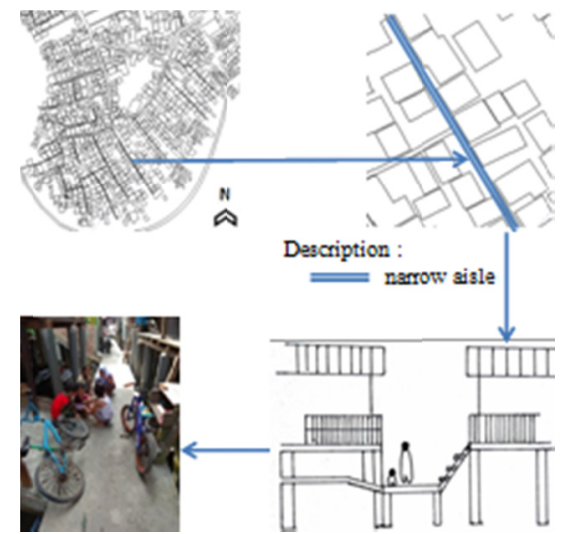

Children's play activities in a narrow corridor

Figure 16. Narrow paths are formed by a row of street-oriented building masses

Corridors or narrow roads in the fishing village of Bagan Deli Belawan Medan are only 1.5 meters wide. The width of the corridor is smaller than the height of the building which has an impact on a very narrow space that is easy to remember (Figure 16).

The atmosphere of the outer space on the corridor is narrow when the tide is high

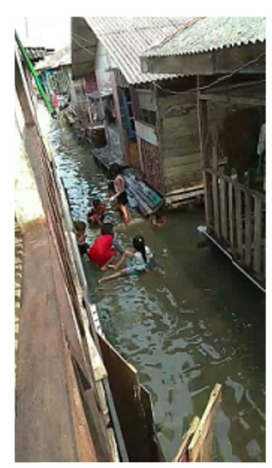


Children in this fishing village also play in a narrow corridor in their respective homes. Usually, children will swim when the tide is high. These children will swim in their yard or the narrow corridor where they live because this narrow corridor will sink by the tides.

\subsection{Spatial Relations Patterns Formed in Fishing Villages Settlement in Bagan Deli Belawan Medan}

Spatial relations are generally formed by the majority of the population who have cultural similarities. This will have a larger decision or agreement, and the formation of such settlements is always determined by the culture of the majority of the local population. This leads to the formation of a residential environment based on the majority of the population. This factor can be seen in the settlement of the fishing village of Bagan Deli Belawan Medan. With the majority of professions as fishermen, the community has a spatial relationship formed by activities that are influenced by profession. As well as when they go to the sea fishermen gather and interact. Then for people who work as non-fishermen usually will work in a warehouse to split and process the catch of fishermen.

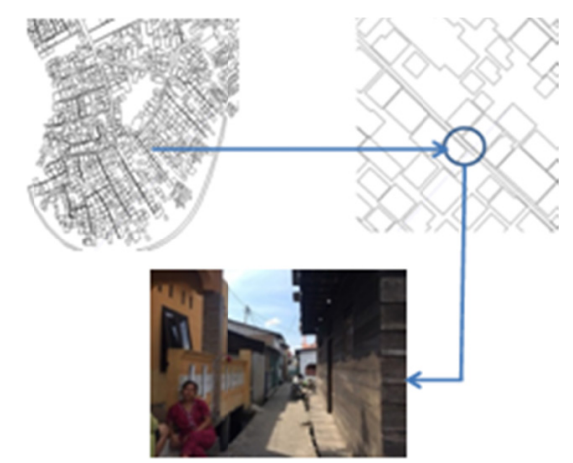

Figure 17. Activities of the neighboring by society at fishing village Bagan Deli Medan

According to Dasnby (1993), the formation of a residential environment is reflected in the relationship between individuals, families, and society (Figure 17). How each relates to the family and the surrounding environment and of course differs from one culture to another, this leads to spatial organization and layout design of residential areas, depending on the view of life. Considering that people in the fishing village of Bagan Deli have similarities in various things such as ethnicity, profession, background, or religion, this facilitates the determination of spatial relationships, and it is also easier to integrate sound and mind because humans are beings who need social and work together. With this similarity is the occurrence of inter-space relations. For example, residents who interact in front of their homes. Communities in the fishing village of Bagan Deli, especially mothers, always use the outer space to interact with their neighbors just to tell stories, chat and so on. This happens in every narrow corridor in the fishing village of Bagan Deli because their house is facing each other. This supports the interaction of the lives of neighbors in this fishing village.

According to Yi-Fu Tuan (1977), to explain the meaning of organizational space in the context of place and space must be associated with culture. Culture has an important role in meaning and forms a space organization. Every individual interacts with other individuals. How space is related to culture depends on the view of each life and each culture has its view. Values about habits and culture have always associated with values of faith or religion that determine the organization of space. It is more likely following a religion that always sorts and arrange space according to functions and benefits in a particular religion or culture. This is made because of the prohibition or taboo of certain cultures or religions that are believed and regulates the organizational space. The need or function of each culture or religion determines what activities will be carried out in that space later. In culture, there are certain laws or taboos in determining the formation of space based on their respective functions. It depends on every society who believes in their respective cultures. For residents of the fishing village of Bagan Deli themselves, the placement of places of worship is very important as is the Nurul Hilal Mosque as the only large mosque as a large meeting between the people and God, a meeting between people and people. The position of Nurul Hilal Mosque is right in the middle, so it also intends to easily access all residents to Nurul Hilal Mosque which is located in the center of the Fishing Village Bagan Deli in Medan.

In addition to the main mosque Nurul Hilal (Figure 18), there are also some of Musholla (small version of the mosque) in support of the worship activities of the fishing village community in Bagan Deli Belawan Medan. It is intended to not always crowded Nurul Hilal Mosque if it requires all people who always want to worship such as daily routine recitations, daily religious activities and primary recitation for children. Nurul Hilal Mosque is always crowded only on certain holidays such as Eid al-Fitr and Eid al-Adha which indeed requires the entire 
community to worship at the main mosque.

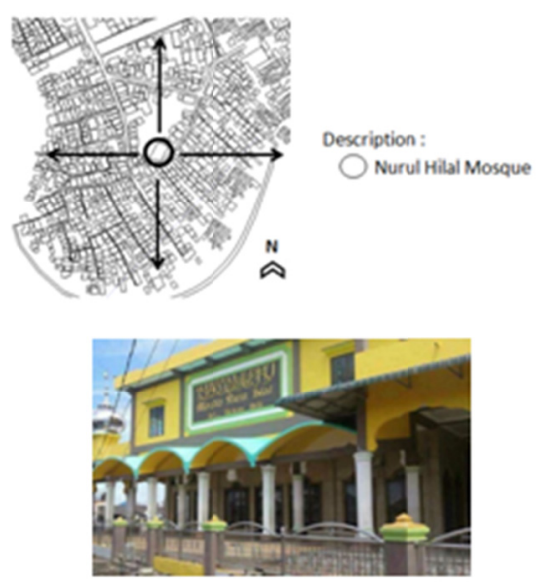

Figure 18. Nurul Hilal Mosque at Fishing village in Bagan Dewli Belawan Medan

Description:

\section{Nurul Hilal Mosque \\ Musholla}

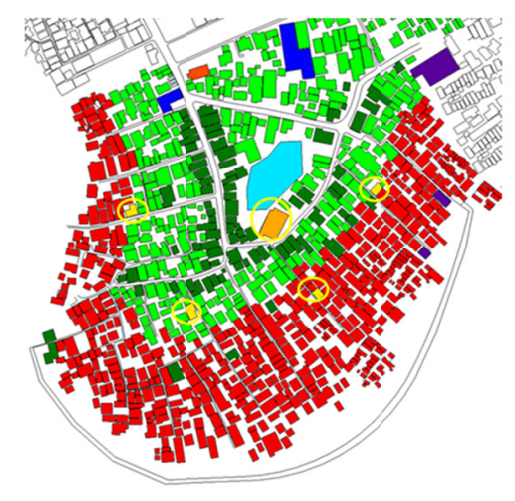

Figure 19. Map of religion activities at the fishing village in Bagan Deli Belawan Medan

Figure 19 depicts Mosques and Musholla as places of worship in this fishing village. This mosque is used for macro worship activities such as the obligatory five-day prayer, Eid-Fitr prayer, Eid al-Adha, and other macro worship activities. While Musholla is only used to study children in this fishing village. Religion is one of the most important elements in its cultural setting. It was marked by the placement of places of worship. Mosques for Muslim places of worship are around the residence of Islamic residents. Malay ethnicity is very strong with the religion of Islam. Therefore there is an Islamic proverb that is Malay, and Malay is Islam. in Malay culture highly upholds the factors of Islamic factors so that they always consider religious factors.

The limited space to play and exercise is the most considered activity in the fishing village of Bagan Deli Belawan Medan. With limited land availability. The playroom is very limited which is only on the main roads, and this forces children to play on the streets. Usually, young people from this fishing village will go out of the village to the outside environment where there are areas or fields for sports such as soccer fields, futsal, and others. However, children in the fishing village also always swim when the tide is in the morning, afternoon and evening. The children in this fishing village will swim under their house building considering their house is a house on stilts that will be flooded with high tides. By Bill Hillier's theory (2007: 311), the building is a very important tool for the community so that the community must adjust all its activities.

Although the community is within its scope, that does not mean that it does not depend on space. This is a social activity. Likewise, social activities such as sports and children play in the fishing village of Bagan Deli Belawan Medan. Children also usually swim in the sea. The Headmen office is also sometimes used by people from the fishing village of Bagan Deli for healthy gymnastic locations. Most likely the father, mother, and child. But this is very rarely done.

The water that is under the building should not be used by the villagers to place children's play activities because, in reality, the water is very dirty. However, the unplanned space between the buildings is the flow of water under the building into a place for children's social activities. Children playing in the water at the foot of the building do not think that dirty and dangerous water will affect and attack their health (Figure 20 \& 21). 
Description:

Main street as playing areas for children Narrow corridors as playing areas or swimming areas for children when the tide is high.

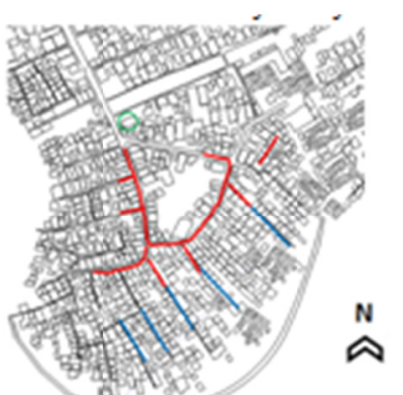

Figure 20. Map of playing and exercising activities in the fishing village of Bagan Deli Belawan Medan

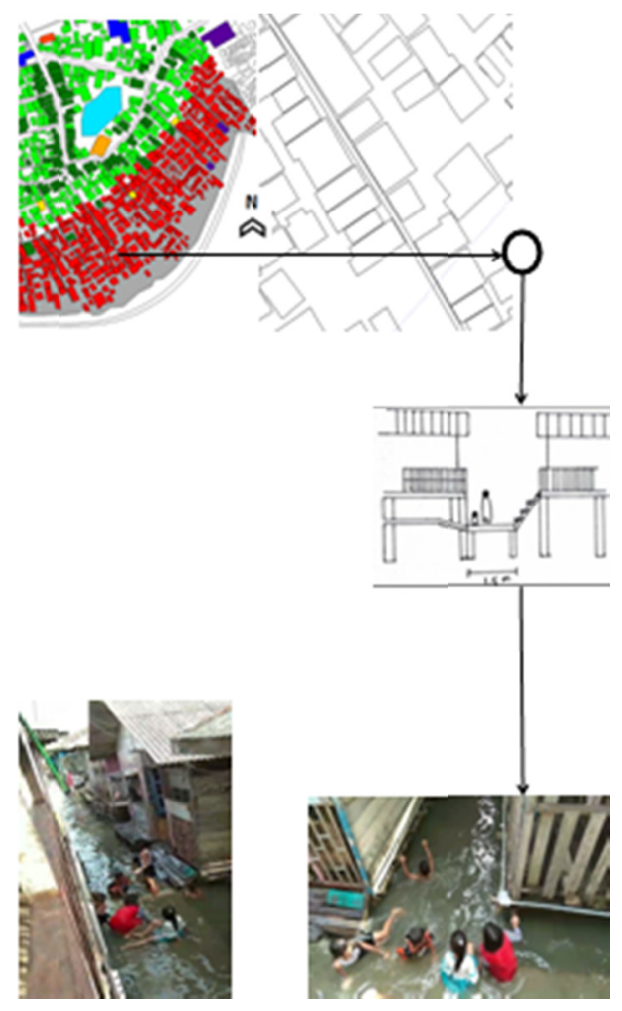

Figure 21. Children play and swim

\subsection{Spatial Configuration of Fishing Village in Bagan Deli Belawan Medan}

The settlement of Bagan Deli Belawan Medan has been built since 100 years ago. The developments in fishing villages were initially controlled only by people without government intervention from the construction of narrow corridors for the determination of residential houses.

Tread conditions are still available

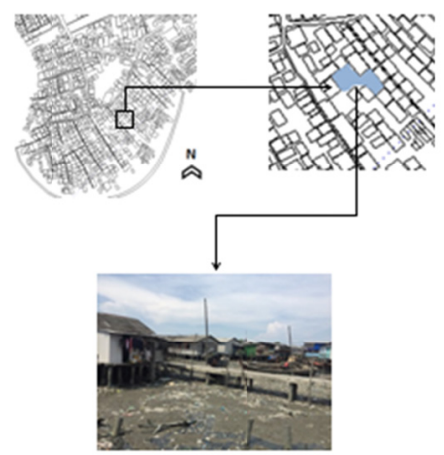

Figure 22. Household footprint 
Spatial configuration is interpreted as a spatial relationship pattern that forms an arrangement so that it has meaning that can be read and understood by everyone. Configuration as a concept that refers to all things that are more complex than apart (Bill Hillier, 2007). Formation of the composition of space begins with an idea or design created from mind and mind. Whether it is an individual idea or group ideas and ideas about the formation of space. This space arrangement is ultimately designed according to the experience of past learning processes to shape, create and design space settings.

In the fishing village of Bagan Deli Belawan Medan, this development began through buildings built following the coastline. This is so that residents easily find the fish, notice that the people who work as fishermen. Then developments continue to occur without any plans that then follow the coastline. The idea of developing this settlement was due to the similarity of the fishing profession. Based on interviews obtained by the researchers, the majority of the fishermen in the village of Bagan Deli Belawan Medan are building their place of residence.

Whether it's a parent's inheritance, hereditary from grandmother and grandmother and choosing their site that is still available (Figure 22). As one respondent said that the one who built his place of residence was the deceased husband with the head of the area who chose the site for his house and paid to the head of the area for site placement. Then, after paying to the local head of area, the certificate will be given as the right of ownership.

The local people take part directly in the construction of a narrow corridor in this fishing village but first when the narrow corridor was still wood and board. Starting in the 2000s, the government began to take part in the construction of narrow corridors by making the entire corridor narrow with cast concrete. The construction of this narrow corridor was built by settlement construction.
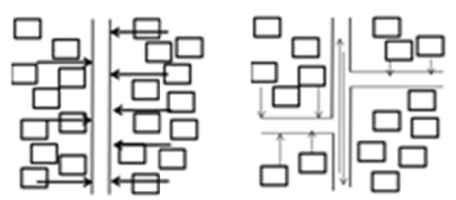

Figure 23. Corridors narrowly adjust the construction of the house

Entering the 2000s, the government carried out construction and renovation of all narrow corridors that were originally made of wood and boards until they were renovated with concrete casting. Built according to existing or newly built houses (Figure 23). The majority of people feel less satisfied and safe with narrow corridors, especially when water is paired in the afternoon or night because this corridor is not visible due to floods inundated.

Description:

hallway / narrow corridor

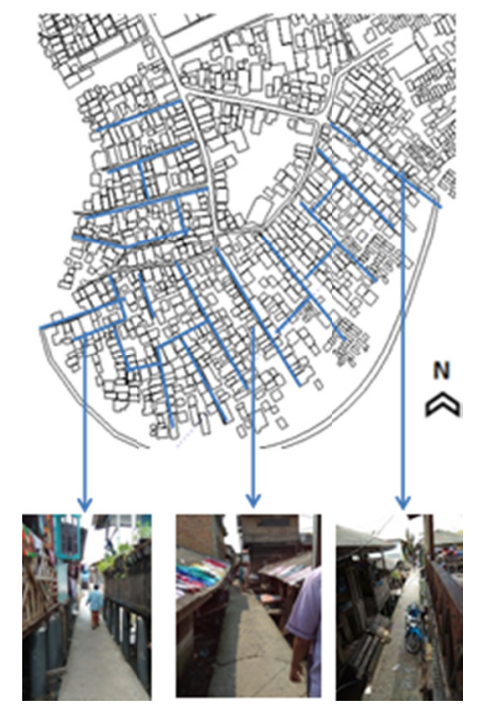

Figure 24. Narrow corridors that are cast in concrete by the government

From the pictures above in Figure 24 narrow corridors built according to existing or newly built houses. The majority of people feel less satisfied and safe with a narrow corridor, especially when the tide is in the afternoon or night because this corridor is not visible because of floods flooded with water or wholesaler. Commercial homes are also a gathering place for people to interact with each other. Coffee shops are usually the majority collected by men after and before the sea they gather at the coffee shop. Whereas for women they usually only interact in front of their homes. The majority of people in this fishing village often use outdoor spaces when 
interacting with their neighbors and feel happy with the hospitality of their neighbors.

According to Andi U.F (2017), the building configuration is arranged linearly following the river's lane and the boundary. The composition of the space that follows a line or a straight line, the composition of this building is an arrangement of buildings that are neatly arranged following a straight line by the river boundary.

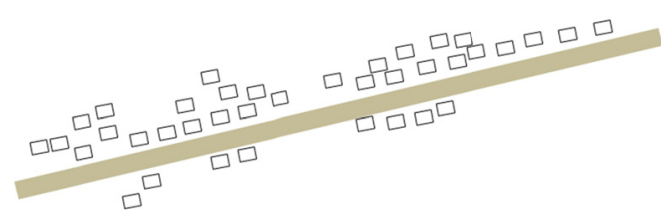

Figure 25. Building configuration is linearly following the river line

Just like ancient traditional societies that rely on rivers as a source of life and the use of rivers as a means of transportation, spatial planning is formed which follows an outline or a straight line which is none other than the river line itself. In the construction of settlements, this fishing village follows the coastline (Figure 25).

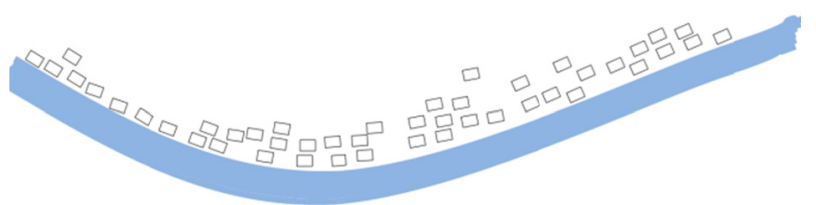

Figure 26. The configuration of the building follows the shoreline

Ancient people in this fishing village rely on the sea as a source of life (Figure 26). Andi (2017) also said the spatial configuration that develops without patterns and is irregular, spontaneous and wild follows the circulation path and layout of existing buildings. Just like the settlement of the fishing village of Bagan Deli Belawan Medan which has a form or form of space that is formed and developed without style, without planning and tends to be irregular, untidy, chaotic, messy and chaotic. Spontaneous, spontaneous, and unplanned arrangements for places are formed because there is an urge to remember the survival of the community, and there is no suggestion from anywhere, wild and untreated arrangements, or straight lines of circulation and layout of existing buildings from afar, governance the location of buildings that have been made from the past and have existed before.

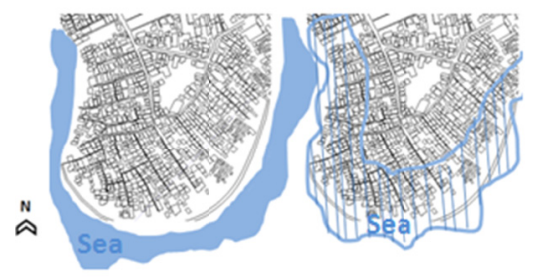

Figure 27. Coastlines are increasingly jutting into the mainland

From the pictures above in Figure 27, the blue line represents the coastline which initially the fishing village community of Bagan Deli began to occupy and follow the coastline as a source of life by utilizing the sea to survive. Then the coastline became more prominent because of eroded waves which forced residents to make and change the physical condition of their houses using boards and wood as a buffer and make it a house on a stage that serves as a protector of seawater when the tide (Figure $28 \& 29$ ).

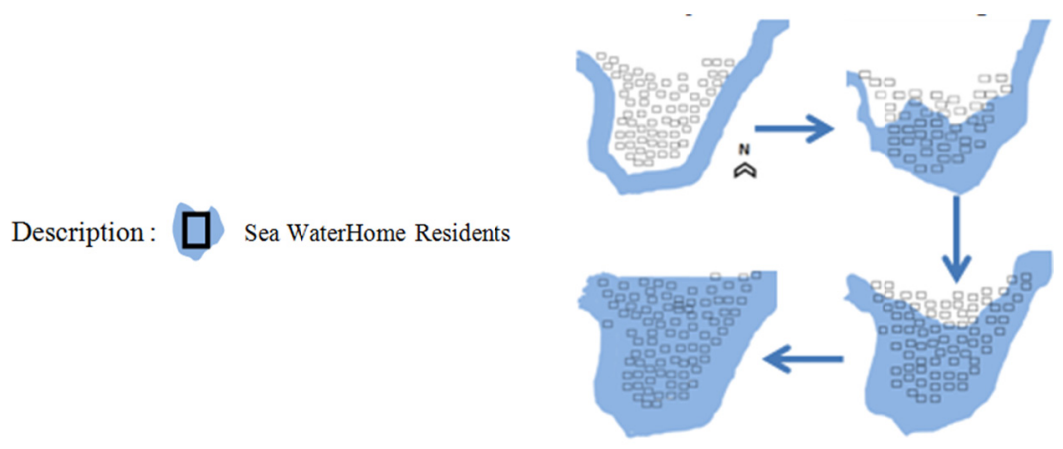

Figure 28. Illustration of shoreline eroded by sea water and waves 


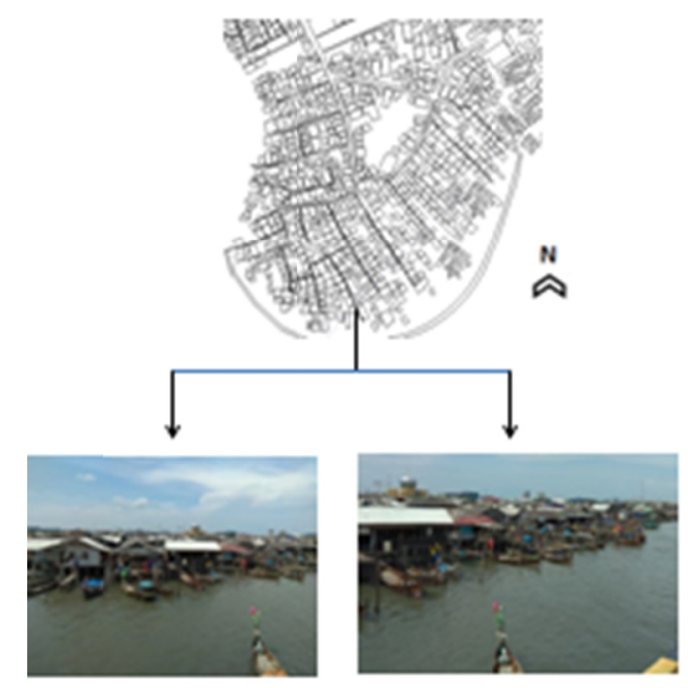

Figure 29. Houses whose treads have been eroded by sea water

The spatial configuration may face constraints on spatial experience because they encourage or inhibit aspects of human activity through subsequent spatial cognition and behavior (Hillier, 1996), which means that settlement spatial arrangements sometimes have fewer constraints and problems with their inhabitants. The experience of space that is felt by the community will encourage or inhibit the point of view of its activities and activities through processes of acquiring knowledge including awareness, feelings, etc. or attempts to recognize something through space experience or its place and subsequent behavior. Activities or processes of acquiring knowledge determine each subsequent behavior and activity. In the sense that the composition of space will always be increased from time to time due to factors of learning or learning from the past and refinement of past spatial errors. The composition of space that changes automatically will change every activity in it. But in the fishing village Bagan Deli, awareness and experience factors recognize space or this place has begun to diminish. It can be proved that from the interview results some respondents have not paid attention to things like this. For example in the construction of a network of roads or narrow corridors in this fishing village.

\subsection{Conclusion}

Settlements in the fishing village of Bagan Deli Belawan Medan are formed because of the need for people to survive. This fishing village community depends on the sea. In general, activities that occur in the fishing village settlement of Bagan Deli Belawan Medan are fishermen as their livelihood, the influence of the activities formed is between fishermen and the sea, fishermen with coffee shops and commercial houses. And then social activities, interacting with residents. Whether it's in the shop or outside the residential building. Children's social activities such as playing and interacting on the main streets and narrow corridors/aisles. Shop using the main road and make it a traditional market in the morning. Trading activities such as those that occur installs and commercial buildings in the fishing village of Bagan Deli Belawan Medan, and religious activities.

Spatial relations in the fishing village of Bagan Deli is formed by the majority of the population who have cultural similarities. This creates a patterned space, as happens in linear space. The activity in linear space affects other spaces. For example, traditional markets affect the space in every outer space of every house occupant in the area of linear space. In addition to activities in the linear space, space patterns also occur in the courtyard of the main mosque in this village. The outer courtyard of the mosque affects a play area for children and where the interaction of citizens when meeting before and after worship.

In the fishing village settlement of Bagan Deli Belawan Medan, development follows the coastline. The community relies on the sea as a source of life and the use of the river as a means of transportation and community livelihoods, then forms a spatial arrangement that follows the outline coastline. Settlements continue to follow existing buildings. The building that originally stood along the coastline will be followed by construction by a new building. Sustainable development occurs because of the needs of the community's residents. The fishing village of Bagan Deli Belawan Medan has the shape and space that forms and develops, without planning and tends to be irregular. The arrangement of places that are formed spontaneously, instantly, and without prior planning, is formed because there is a memory of the heart for the survival of society. 


\section{Acknowledgments}

Research on Spatial configuration of the fishing village in Bagan Deli Belawan Medan Indonesia, to providing an integrative approach for Understanding the life sciences. The funding source of this research is Directorate of Research and Community Service; The Directorate General of Strengthening Research and Development at the Ministry of Research, Technology and Higher Education is following the Agreement for the Implementation of Research for the Budget Year 2019 Number 11/ E1 / KP.PTNBH/2019, 29 March 2019.

\section{References}

Andi, U. F. (2017). Pengaruh Jaringan Perdagangan Global Pada Struktur Wilayah Dan Konfigurasi Spasial Pusat Pemerintahan Kesultanan-Kesultanan Melayu Di Kalimantanbarat. Langkau Betang: Jurnal Arsitektur, 4(1), 67-78. http://dx.doi.org/10.26418/lantang.v4i1.20395

Burhanuddin, B. Karakteristik Teritorialitas Ruang pada Permukiman Padat di Perkotaan. JURNAL ARSITEKTUR, 2(1).

Farmer, B., Louw, H. J., Louw, H., \& Napper, A. (2003). Companion to contemporary architectural thought. Routledge. https://doi.org/10.4324/9780203168578

Hillier, B. (2007). Space is the machine: A configurational theory of architecture. Space Syntax.

Hillier, B., Leaman, A., Stansall, P., \& Bedford, M. (1976). Space syntax. Environment and Planning B: Planning and design, 3(2), 147-185. https://doi.org/10.1068/b030147

Kim, Y. O. (2001). The role of spatial configuration in spatial cognition. In Proceedings of the Third International Space Syntax Symposium, Ann Arbor, The University of Michigan (pp. 49-1).

Koentjaraningrat, R. M. (1970). Manusia dan kebudajaan di Indonesia. Djambatan.

Omer, I., \& Goldblatt, R. (2016). Spatial patterns of retail activity and street network structure in new and $\begin{array}{lllll}\text { traditional Israeli } \quad \text { cities. } & \text { Geography, }\end{array}$ https://doi.org/10.1080/02723638.2015.1101258

Peponis, J., Wineman, J., Bafna, S., Rashid, M., \& Kim, S. H. (1998). On the generation of linear representations of spatial configuration. Environment and Planning B: planning and design, 25(4), 559-576. https://doi.org/10.1068/b250559

Rapoport, A. (1973). An approach to the construction of man-environment theory. Environmental design research, 2, 124-136.

Tuan, Y. F. (1977). Space and place: The perspective of experience. U of Minnesota Press.

\section{Copyrights}

Copyright for this article is retained by the author(s), with first publication rights granted to the journal.

This is an open-access article distributed under the terms and conditions of the Creative Commons Attribution license (http://creativecommons.org/licenses/by/4.0/). 